ÉGYPTE monde arabe

\section{Égypte/Monde arabe}

$34 \mid 1998$

Droits d'Égypte : histoire et sociologie

\title{
Dilemmas of religious reform (Islâh)
}

Reinstitutionalizing sharî'a

\section{Armando Salvatore}

\section{(2) OpenEdition}

\section{Journals}

Édition électronique

URL : https://journals.openedition.org/ema/1503

DOI : $10.4000 /$ ema. 1503

ISSN : 2090-7273

Éditeur

CEDEJ - Centre d'études et de documentation économiques juridiques et sociales

Édition imprimée

Date de publication : 31 décembre 1998

Pagination : 99-114

ISSN : 1110-5097

Référence électronique

Armando Salvatore, « Dilemmas of religious reform (Islâh) », Égypte/Monde arabe [En ligne], 34 | 1998, mis en ligne le 08 juillet 2008, consulté le 07 juillet 2022. URL : http://journals.openedition.org/ema/ 1503 ; DOl : https://doi.org/10.4000/ema.1503

Ce document a été généré automatiquement le 7 juillet 2022

Tous droits réservés 


\title{
Dilemmas of religious reform (Islâh)
}

\author{
Reinstitutionalizing sharî'a
}

\section{Armando Salvatore}

1 This article discusses the metamorphosis of Islamic traditions that is due to their increasing exposure to global communication and legal regulation. It focuses, in particular, on the historical alteration in the understanding of shari' $a$ in Egypt caused by the modernization of state rule, the reform of the legal system, the emergence of a modern press and a modern public sphere, and the process of reform (islâh) of Islamic traditions that engaged significant portions of the religious and intellectual elite.

2 The discussion first reconstructs the process of legal-judiciary deinstitutionalization and normative reformulation of sharî'a that corresponds to the classic phase of islâh, linked to the name and work of Muhammad 'Abduh (1849-1905). It then addresses the dilemmas faced by those "late-classic" reformers or even "post"-reformers, who were confronted, around the time of the demise of the caliphate in Instanbul (1922-24), with what they perceived as a tabula rasa in sharî'a's institutional rooting. They, therefore, sought to fill this vacuum by capitalizing on the reformulation of Islamic norm performed by the classic islâh in order to sketch new paths of institutionalizing sharî'a. With the exception of the reconstitution of the caliphate, these debates and projects which date back to the 1920s, along with their dilemmas, provide a historical background - as well as a historical memory selective drawn upon - for the so-called sahwa islâmiyya, the "Islamic awakening" movement that flourished in Egypt during the 1970s and 1980s. Article 2 of the new constitution of 1971 proclaimed sharî'a a main source of legislation, and the amendment of 1980 further enhanced sharî'a to the main such source (Salvatore, 1997).

3 The Islamic sharî'a (al-shari'a al-islâmiyya) is the religious norm that Muslims consider the emanation of God's will (shar), as revealed in the Koran. The grade, intensity, and extension of sharî'a's normative power vary considerably both historically and geographically. The construction of sharî'a as a conceptual tool defining an entity-like normative system however, has been gradual. It is not built into any particular legalcultural repertoire residing either in scripture or in the historical experience of the protocommunity (the umma) of Muhammad, his companions, and the first rightly- 
guided caliphs. "The sharîa is a concept with which Islamic thinkers in the formative and classical periods were not concerned" (Smith, 1965:585).

The present investigation seeks to evaluate the impact of global communication, within modem public spheres, on the metamorphosis of this particular moral-legal dimension of Islamic traditions. This process of alteration caused by global constraints cannot be simply reduced to linear pressure on sharîa to become a mere tool to affirm a particular identity, or to assert the belonging to an autonomous legal tradition (a claim of "legal identity"). The analysis will describe how the enduring - though rapidly metamorphosing - transcendence-bound, specifically religious rationale of sharî'a has, within the broader current of islâh, been the object of interpretative contest and competing projects of reinstitutionalization of divine norm within a modern legal and political landscape.

Globalization, in this context, does not so much imply the constraints of state-building and state-centralization projects pursued by Muhammad 'Ali and his successors in Egypt in the wake of the increasing market and financial interdependence of Egypt with Europe during the 19th century, which required the efficient mobilization of the working force and the enactment of measures to secure national control over the whole process (for a pioneering work on this "political economy" dimension of globalization, see Gran, 1979). Globalization, here, refers to the requirements of legal regulation and intellectual communication in the public sphere that followed the centralization of state authority, in the context of increasing colonial influence, and that led to the concomitant reform of the legal and judicial system and to the rise of a modern press. In both cases, and as a common rationale, this process can be defined as the rise of autonomous professionals of law and of intellectual communication who were faithful to the new national project, but did not become mere instruments of the ruler's policy priorities which, in any case, was severely restricted by British colonial presence.

6 This presence represented the most recent chapter of century-long European influence in Egypt, where the French, after Napoleon's military occupation (1798-1801), had been prominent in lending a legitimacy to modern canons and disciplines of law, education and discourse rationality, by acting as advisers and planners in several branches of the administration (cf. Alleaume, 1989 and Goldberg, 1997). This influence, however, was hardly one-sided as Egyptian cultural elites did not partake passively in the new public and intellectual game linking Egypt to Europe during the 19th century. Much attention has been devoted to the case of shaykh Rifâ'a al-Tahtâwî (1801-1873), graduate of the Islamic university al-Azhar, who had a formative influence on the Egyptian public sphere, even prior to the rise of autonomous press organs that no longer fulfilled merely administrative channels of communication, between the 1860s and 1880s. In his contacts and exchanges with French society and culture and, in particular, in his encounter with French intellectual and legal rationalities, al-Tahtâwî gained the intellectual power and legitimacy needed to implement reforms with greater expertise. He believed that he was reshaping a renaissance of Islamic knowledge and social power. He translated the French civil code into Arabic, seeing it as a valuable tool of civilization and state power.

7 When speaking of globalization - such as the globalization of normative frameworks a more compelling force is evoked than that at work in the culturally rich and politically tense environment within which al-Tahtâwî developed his intercultural competencies in shaping a proto-national project of social reform. The process of 
restructuring the understanding and public influence of shari'a, which occupied the agenda of islâh from about the time al-Tahtâwî died onward, is a good case of how globalizing influences work unpredictably in national contexts, enhance social complexity, and multiply the fields where rationalities of law claim to regulate social transactions. Globalization, in this case, is a catalyst of complexity. The autochthonous ruler, the older and newer intellectual elites, and the colonial power largely lost control of the monitoring of social reform and transformation. This complexity is the result of the formation of rationalities specific to subsystems of social action and communication and is indifferent to rules of reason claimed as valid for all society. At stake here is the development of an increasingly unbridgeable tension between the reform of the legal system and the visions and ambitions to reform the moral norms of society. The metamorphosis of sharîa isto a large extent located in this field of tension and driven by attempts to bridge the gap. This tension is neither specific to the modernization of Muslim societies nor to colonized societies, in general. It is also inherent in the modernization of normative frameworks and legal institutions elsewhere.

Some historical evidence suggests that, in the time prior to the modem state-building of the 19th century, the legal function of at least those religious specialists ('ulamâ')engaged as judges, qâdî-s (differently from the muftis, who are dispensers of advisory legal opinions) became well differentiated from the general function of knowledge and guidance demanded of 'ulamâ' (Johansen, 1988 and 1993). Modern statebuilding, before the rise of a public sphere, completed this differentiation by increasingly stripping the formulation-interpretation of law from the formally independent, religiously trained jurists, and making it a competence of state authorities. In the process of transition, the juridical personnel and institutions nurturing this religious law lost their legal competencies at the advantage of new courts set up by the state, but were not disrupted. These religious specialists were forced to engage in a process of revision of their social role: sometimes unwillingly, under the pressure of a state desirous to restrain them, sometimes more actively, through the stimuli of contests in the newly created public spheres, and sometimes by an impulse of reform developed by some 'ulamâ' under the double incentive of statebuilding and of debates in the public sphere over issues of social welfare and of common good. A new normative view of consensus within the community (the umma) emerged in the process.

Different from the idea of Arab-Islamic "renaissance" (nahda), based on civilizational rebirth, as protagonists and observers of the reform process liked to describe it, the islâh comes close to expressing a reflexive concern with subjective becoming in history. Though it has some rooting in the Koran, the first conscious self-identification of some thinkers as committed to the islâh is contemporary to, and complementary with, the process of reification of Islam that has taken place in public discourse since the end of the nineteenth century in the Egyptian public sphere. At that time, in titles of books published in Arabic, Islam as the more "systematized and externalized" term for the Koranic din, outnumbered the "personalist and activist" term imam by a ratio of over 13 to 1 . Since that time, îmân has virtually disappeared from the headlines of public discourse, which has been solidly hegemonized by Islam (Smith, 1962:114-17).

Islâh represents a blueprint for reconstructing an original tradition in Islamic terms, by building on it modem claims of a collective identity. The propagators of islâh liked to 
feel they were in line with the chain of cyclical reformers initiated by Muhammad and anticipated by him in a famous hadith. The feeling of intellectual distinction is conveyed in conviction that reformers of Islam since Muhammad have always been "alone (ghurabâ) in the world" (Merad, 1978:141-42). In this sense, the reform as "concentrated on the need to improve, correct, reorganize, renovate and restore" (Merad, 1978: 144) embodies a will to legislate over a reluctantcommunity by restoring the allegedly pristine model of discipline of the subject and regulation of intersubjective relations. This is no contradiction, since the word islâh signifies "performing the good" in the assumption that the good is known, as incorporated in the idealized Islamic community. In the final analysis, the legitimacy of islâh is that it reflects the fulfillment of the canonical injunction of "commanding good and prohibiting evil," on which the muslihûn based their idea of what the regulating authority of the faithful should be (Merad, 1978:141). The actual content of "reform," however, depends on working out the societal needs of the time, as reflected in the enhancement of maslaha 'âmma or simply maslaha (the general interest or public good) as a main source of lawfulness. Translating islâh as "reform" is therefore reductive. The major scope of islâh was a new definition of the Muslim subject and his moral endowments, making his conscience the hub of virtuous action which is finalized by helping other members of the community correct their errors and vices. This was no political program. 'Abduh had a disparaging view of politics (siyâsa), in spite of his judiciary responsibilities and his attempt to attain wide public support for his teachings. State institutions were important tools to carry out the disciplining and civilizing project of islâh, but were not the ultimate scenario of social, morally guided, action and communication.

11 As a result, despite the fact that Muhammad's community functioned as a model, islâh'snovelty is that it replaced an arbitrarily sacralized Consensus of the community (ijmâ) with another kind of consensus, based on the immanent rules of public communication, that placed a bonus on the public use of reason for discussing issues on society's common interest. In this context, the goal of Islamic reformism is the final deconstruction of ijmâ' andthe revitalization of ijtihâd ("free reasoning" in the determination of binding truth) as an instrument for working out solutions beneficial to the life of the umma and its welfare. This was no mere theoretical stance, since the practice itself of reformers was to perform ijtihâd in such a way as to best capitalize on its public impact. The most famous work by Muhammad 'Abduh, Risâlatal-tawhîd (1897), is prominent not so much for the degree of doctrinal innovation, but for the way in which it publicly conveys a highly compact and easily readable message of reform in a virtually journalistic style (Merad, 1978:159).

In its discussion of islah, Western literature highlighted how its calling for an adaptation of the legal-moral competencies of 'ulamâ' and of all Muslim citizens to the requirements of a modern society finally resulted in defining shari'a "in terms of its empty spaces" (Kerr, 1966:210). This interpretation comes close to revealing the internal inconsistency of any attempt at reform within Islamic traditions or even their basic non-reformability. It is also possible to reinterpret the reform blueprint as aiming to formulate the vocabulary and the rules, the meta-language and the "metanorm,"of the public sphere that was shaped in Egypt between the 1860s and 1880s, in the context of the expanding scope of the press from merely the mouthpiece of political authority - intent in rationalizing communication down the echelon of an even more complex bureaucracy - to a forum of expression for the political and cultural aspirations of an intellectual class in upheaval. In the case of religious reformers (the muslihûn), this 
transformation encouraged them to conceive their islâh as a reconstruction of divine norm by focusing on the subject and its disciplining and by assembling different strands of canonical observance and obligations around a much stronger notion of the Muslim as individual, believer and citizen (al-Kûmî, 1992). Reformers thereby redesigned the normative consensus in the public sphere, by assuming they were purifying a religious tradition corrupted by undue innovations and by sharing the definition of the actual public agendas of the emerging nation-state politics.

In a certain sense, the shari'a, as evoked today in both its morally "personalizable," and legally "systematizable" dimensions, was born out of these transformations. Crucial, among them, was the gradual deinstitutionalization - more than abandonment (Brown, 1997) - of the religious law administered by 'ulamâ' trained as jurists (fuqahâ) within al-mahakim al-shar'iyya, the "religious courts", or more precisely the "tribunals of the divine norm" (the shar). The major rupture in the competencies of these courts, before their suppression and incorporation of their residual functions on matters of personal status into the state system in 1956, was the institution in Egypt, in 1883, of almahakim al-ahliyya, the "national", or "indigenous" courts. In retrospect, since their suppression, al-mahakim al-shar'iyya have been called "sharî'a tribunals" by Western analysts and actors. This appears 'to be an inverted anachronism, since this view of shari'a, a pretended shari'a regulating subject and system, was much the product of the process that led to the disempowerment of these courts. But, this normalization process of the past and construction of a normative tradition is not particular to sharî'a. Any normative order fiercely negates that it was born at a certain moment in history through an arbitrary normative volition, through power games, via the selection of commandments and their inscription into tables, through social differentiation. Law must never "begin" (Luhmann, 1995:138).

In this process lies the formation of a "new" normative discourse on sharî'a that bridges the gap between the traditionally revered divine norm, revived and given a new meaning in the face of modernization and the law, intended as positive, "secular" and issued by a sovereign state. This law is respected and feared as powerful and necessary, though viewed as a tool to regulate social behavior and discipline social subjects, a view that religious reformers largely shared with stateauthorities. "Secular" intellectuals regarded divine norm and secular law in another light. They were more immediately fascinated and gratified by the new autonomous lawfulness of a growing state sustained by a vital nation (a process made more complex and dramatic in Egypt by the British military occupation of 1882, that was followed by the imposition of different degrees of control on several branches of the state machinery). These intellectuals - most of whom were prominent legal professionals who graduated in state law schools - sought nonetheless a dialogue with religious authorities. By revering the divine norm in their own way, they became entangled in the same kind of puzzle faced by religious reformers: how to redefine the relationship between an abstract lawfulness derived from God's commandments, which could not be deprived of its divine legitimacy and transcendent reference by a simple fiat of a state authority, and institutional legality.

This differentiation, tension, and will to harmonization, which involved abstract normativity and a legal system, lawfulness and law, did not result, during the classic era of islâh, in loud claims to recuperate the legal efficacy of sharî' $a$ and implement its newly assembled normativity within the system of positive law. In the period immediately preceding the institution of the national courts, the Egyptian Minister of 
Justice, Muhammad Qadrî, had worked extensively on a project of codification of sharî' $a$, but with the exception of laws of personal status, for which the religious courts were allowed to keep their competencies, the national courts adopted Trench-style" codes, designed to suit a "French-style" system of tribunals. However, aside from the form and structure of codes and courts, which best suited the imperatives of order and control of a fast centralizing state (even more so since, at the time, it faced a traumatic colonial penetration that never reduced it to a "colony"), many elements of islamic law, in its new codified form, were integrated into the codes.

The decision to downplay the influence of a newly conceived and codified shari' $a$ on the codes was more pragmatic than strategic. It sought to provide the new courts with a law already experimented in the mixed courts, introduced in 1876 to handle cases where interests of a European power were at stake (so as to overcome consular jurisdiction in cases involving Egyptian citizens). Its aim was to avoid giving the military occupant a pretext for discrediting or manipulating this important tool of state modernization and national independence. It also sought to gain European acceptance to suppress the mixed courts, themselves considered an unacceptable vestige of foreign influence (Brown, 1995: 115-118). The move was probably not intended by any major Egyptian actor as a rebuttal of sharî'a, but as a convenient step in keeping its influence discrete and invisible, in a period when the task of transforming the corpus of legal regulations, recorded in texts of figh of different schools, into standardized, unified codes was still in its early stage. This absence of public zeal in upholding the visibility of shari'a in the new codes may point, not to its dismissal, but to a blend of contingent political wisdom and technical immaturity. In time, the jurisprudence of the national courts even enhanced the shari'a'stenor of the applied "French law".

Jurisprudence, however, does not make headlines, and the perception of the fate of sharî' $a$ changed swiftly and dramatically in the socio-political climate of the 1920s. The suppression of the caliphate in Istanbul was an important emotional component of the change in the political-intellectual climate. A more immediate factor, however, gave momentum to the reconstruction, reinstitutionalization and enforcement of sharî'a. Amidst increasingly successful national agitation, after the revolution of 1919, and formal independence in 1922, which diminished British influence and control, the link between normative contests in the public arena and the implementation of a constitutional and legislative policy became more important than ever in modern Egyptian history. Bridging the gap between norm and law became imperative for those interested in upholding shari' $a$ 'slegal and institutional appeal and effectiveness in the modem world, beyond the seemingly untouchable kernel of personal status law.

It was, in particular, during the 1920s that Muhammad Rashîd Rida (1865-1935), the radical disciple of Muhammad 'Abduh, consciously constructed Islam as a principle of societal and political cohesion. This, however, was clearly to be anchored in the conscience and action of the individual Muslim, called to manifest the capacity to harmonize spiritual motivation and social engagement (Rida, 1988 [1922]: 74). Rida claimed, accordingly, that the efforts towards islâh had to focus on the conscious formulation of a solution to the problem of the imâma, i.e. of the leadership within the umma, by constituting the latter as jamâ'a. Jamâ'a is a sort of willed community and sovereign society that functions on the basis of a new consensus worked out by the 'ulamâ'according to principles of justice and equality among all believer-citizens, 
principles that Rida considered essential to the islâh and to the injunction of "commanding good and prohibiting evil" (al-amr bi-1-ma'rûf wa-l-nahi 'an al-munkar). He was very explicit in asserting that there cannot be any nahda except through Islam and, in particular, through the Arab people that constitutes Islam's source of origin (Rida, 1988 [1922]: 74-77; on Rida and politics, cf. Dupret, 1995).

The caliphate is reinterpreted as the supreme instance of legitimacy of the project of islâh within the Islamic community. This centrality is nonetheless conceived as perfectly compatible with the reality of the nation-state. The result is a Utopian vision of the political import of public communication as governed by Arab-speaking scholars exercising ijtihâd. It fits the political structures and technologies of domination of the existing states, and envisions the institutionalization of Islam as dîn siyâda wa-sultân, i.e. as religion of sovereignty and domination (Rida, 1988 [1922]: 93-94). It is formed within the Islamic public sphere, of consolidating Muslim-Arab nation-states, and provides the terrain of legitimacy and self-representation of reforming 'ulamâ', who irradiate their legislating authority directly upon the consciences of Muslims within the jamâ'a, and thereby elevate each of them to a free, self-conscious mujtahid (practitioner of ijtihâd) of God's will (shar') (Rida, 1988 [1922]: 115-16).

In this view, any Muslim-citizen is entitled to withdraw his obedience to the imam whenever the latter misinterprets the shar' (Rida, 1988 [1922]: 133-34). The guarantee of this duty-right, which is essential to the functioning of the caliphate, is seen in a modern constitutional framework (Rida, 1988 [1922]: 148). The Utopian neo-hanbalite vision of the fulfillment of the truth on earth, by keeping alive the Prophet's charismatic leadership, is fertilized through a constitutional approach that takes account of the reality of the nation-states. It also, however, attempts to transcend it by invoking a supreme instance whose purpose it is to reconstitute a principled community that incarnates the perfecting and universalizing impulse of Islam. This vision operates along an axis that anchors the subject within the system by emphasizing the primacy of public and inclusivist ethics, a task that existing states are considered unable to perform, as they are inevitably bound to an exclusivist 'asabiyya (particularistic force of cohesion).

With Rida, the shift in the doctrinal and practical understanding of ijtihâd, the faculty of finding innovative legal solutions through free reasoning that Islamic jurisprudence had confined to very special cases, and only accorded to particularly talented spirits, is complete. In historical terms, the "gate of ijtihâd"was never closed, but rather restricted to cases that were not crucial to the actual functioning of the legal system - as it evolved and was consolidated - thereby reducing the margins of individual arbitrariness (Hallaq, 1984). Through a concerted adaptation of the system to evolving circumstances, innovation was permissible, but only by invoking the ijmâ', i.e. the consensus of the jurists. In the era of the public sphere, a new emphasis on ijtihâd emerged along with a previously unknown, emphatically constructed opposition to taqlîd, along with a distancing from the ijmâ'. Both were often perceived as fostering the unwillingness of the 'ulamâ' to take up the challenges of the modern world. If evaluated from the viewpoint of the legal system's pace of reform, this position was out of touch with reality. By the time the legal system, based on traditional divine law and its literature and practice of jurisprudence (figh), was called to cope with these challenges, it was being swiftly deprived of its institutional competencies, without significant objections by religious reformers (Brown, 1997). At this stage, however, ijtihâd was 
propagated, quite consciously, not as a technical-juridical skill of excellence, or a device for updating the legal system, but as a method to regulate and encourage participation in discussions on issues of common interest, to foster a moral and discursive discipline to addressing such questions, and to establish a new view of lawfulness and a new consensus of communication in the public sphere and in society at large. Ijtihâd wasexpanded from a classic method, which dilated the normative import of scripture via independent reasoning, into a discipline of rational-critical debate in the public sphere. Its practice would best capitalize on public impact and establish the legislating authority of reason only bound to the Koran.

The myth of the closing of the gate of ijtihâd, and the call to reopen it, might have been created by those religious reformers eager to turn consensus, from an exceptional and exclusive mechanism of infra-scholarly accommodation, into a permanent and inclusive mechanism of scrutiny establishing sound arguments based on the judgment of an impersonal, potentially ubiquitous "public." The period between the 1880s and the 1920s saw an "essentialist" implosion of sharî'a from its previous positive, systemic and institutional efficacy, to its pretended authentic, normative kernel. This kernel was reformulated not merely under the pressure of a syndrome of identity-construction or an obsession with authenticity, but according to the new rules of the public sphere, its metanorm and the "new" consensus.

The project of islâh played on a triple register, which is typical of any historical constitution or major transformation of a public sphere. Law, as a particular form of regulation of human behavior and social transactions, was instrumentally called to provide the intermediate term bridging the gulf, through the disciplining mechanisms specific to legal enforcement, between two other elements otherwise difficult to compound in practice: the construction of models of personal virtue, and the approach of a metanorm expected to allow rational communication within the community. The useful fiction of metanorm consists in providing the public sphere and its actors with a unitary vocabulary - a homogeneous normative staging ground (Salvatore, 1998). A problem arises when the invocation of law becomes an overly ancillary fiction in the game, and slides away from the control of public sphere heroes, old and new intellectuals.

24 A book from the same period, by the Egyptian 'âlim 'Alî 'Abd al-Râziq (1888-1966), alislâm wa-usûl al-hukm (Islam and the Fundaments of Rule, 1925), mainly assessed as championing a "liberal" and "secularist" approach to Islam, should be placed in its historical context, within the trajectory of islâh and its dilemmas on how to bridge the gap between norm and law, between authority and institution. 'Abd al-Râziq's essay represents the culmination of the reforming endeavor that reached, with. Rida, a point of no return. In spite of the basic admission of the contingent character of power in the Islamic community, politics in its modern shape was claimed to be resubjected to faith. This was much of a weakness and theoretical impasse,which also trapped those analysts engaged in making sense of the "Islamic revival," and who ended up reducing it to "faith-driven politics."

'Abd al-Râziq instead performed a radical de-conflation of faith and politics in a way that was still consistent with the original Utopian view of islâh. Dissociating politics from faith was seen as the only way to revive the credibility and authority of God's will, and sharî'a itself. First, 'Abd al-Râziq agreed with the general inclination of islâh not to radically challenge the Consensus of the community (ijmâ) on a doctrinal level, in spite 
of tension with the reinvigoration of ijtihâd ('Abd al-Râziq, 1925:22). His goal was rather to render its applicability questionable over the issue around which the stake of consensus was politically the highest: the invocation of ijmâ' for establishing that Islam prescribes the organization of political authority as a religious obligation. He did not hesitate to denounce the hypocrisy of the juridical argument that, suppressing any effort to rationally analyze the fundaments of political power, constructs the fiction of the investiture of the caliph (bay'a) as legitimated by the Consensus. Historical reality shows that with rare exceptions, the caliphate was founded on the basis of brutal force ('Abd al-Râziq, 1925:23 and 31). Following this argumentative logic, 'Abd al-Râziq straightforwardly made tabula rasa of those arguments that obstructed a critical consideration of the reality of power and of its relation to Islam as din. He performed this task with a deconstructionist vehemence completely absent in Ridâ's argument, in spite of the latter's similarly innovative approach to the Consensus.

On the other hand, 'Abd al-Râziq was very eager to stress that the Koranic din is a religion not limited to teaching the principles of fraternity and equality, but also to actively educate its followers to practice these precepts and, above all, to forge norms inspired by them ('Abd al-Râziq, 1925:27). Here, he clearly establishes that Islam constitutes, besides din, and as a consequence of its special character as din, a principle of civic life, thereby affecting the dunya, the worldly environment with its social obligations. Islam is a madhhab (path, teaching, but also movement) of islâh for all mankind ('Abd al-Râziq, 1925: 76). The Islamic community is still considered as given by, and bound to, kullu ma shara'ahu al-islam ("all that Islam prescribes"), from which only al-hukm al-siyâsî, the vertical dimension of organization of the community, is excluded ('Abd al-Râziq, 1925:84).

An essential point of this argument is that since Islam is this special sort of socially expanded din, grounded on values of equality and fraternity, Islam cannot grant to any established power the necessary legitimacy. As a result, Islam is din la dawla, religion but not state ('Abd al-Râziq, 1925: 64). In this way, 'Abd al-Râziq symmetrically countered the slogan of Islam din wa dawla, which began to be very popular at the time of the demise of the caliphate. Seeing beyond this slogan appearedto be crucial in order to eradicate the ambiguities of islâh towards the problem of the religious legitimization of power, and to consolidate the process of modernizing the basis of the consensus, by making it dependent on communication and the strength of public argument. According to the same logic, 'Abd al-Râziq provocatively argued that if the fuqaha' (Islamic jurists) mean by caliphate or imamate nothing more than what the political scientists mean by "government," they were completely right to claim that the welfare of the governed people depended on such an institution. In this case, however, they were stating the obvious. Any addition to this simple truth, leading towards the establishment of the imamate as a special, since religiously grounded, sort of government, would be unjustified ('Abd al-Râziq, 1925:45).

Ridâ's argument was similar to that of 'Abd al-Râziq before reaching the point where it was forced to justify the caliphate. It follows the claim that, though authority belongs only to God and His Prophet, the shari'a cannot be implemented without a supervising authority that institutionalizes and keeps alive - thereby remaining faithful to the tradition of islâh - the charismatic gift of prophecy given to mujtahid-s of any epoch. As the supreme imam, the caliph would not simply be a replica of temporal power, but the highest 'âlim practicing ijtihâd and exerting influence, in this indirect, moral way, on 
existing governments of Islamic countries (Hourani, 1983 [1962]: 240). Rida's ultimate point was not even on the political influence of such authority on the individual and social lives of Muslims, but on the necessity of making publicly visible and constitutionally accountable an institutional representation of shari'sis centrality as the manifestation of God's Will. In this sense, Rida was unable to issue a realistic project of reinstitutionalization of sharî'a in the constitutional and legal landscape of the rising Egyptian nation-state. He remained trapped in the metanormative, moral, and disciplining framework of classic islâh.

Was Ridâ's view a mere accident of intellectual history contingent on discussions about the reconstruction of the caliphate of that particular historical juncture, to be forgotten forever, an ultimate token of the impossibility of a modern Islamic public sphere to find adequate channels of institutionalization in the political and legal systems of the time? His reconstruction of the institutional basis of shari'a'slawfulness was neither an attempt to resurrect older forms of institutional and legal mediations, nor realistic enough to interfere with the constitutional process and the process of reform of codes. On the other hand, 'Abd al-Râziq's deconstructionist vehemence aroused outrage and scandal during the 1920s. His work was very much a sign of the time, a brutal self-diagnosis of islâh, but its contingent misfortune was due to the fact that it offered no practical answer to the question of how to reinstitutionalize shari'a. However, a much more specifically legal-technical work of reconstruction of shari'a through selection and codification of concrete rules and prescriptions of Islamic jurisprudence (that had scored a first major achievement during the classic period of islâh in the work of Muhammad Qadrî, however compelled to recede quickly behind the form of "French law" when it was decided about the codes to be adopted by the National Courts), was revived with more success in the same climate of the 1920s, affected by the ferment surrounding the issue of the caliphate. This was a project intellectually affiliated to the islâh, trying to approach the corpus of figh through the new (meta)normative conception of shari'a propagated by the reformers.

'Abd al-Razzâq Ahmad al-Sanhûrî, later to become the architect of the new Egyptian civil code (promulgated in 1948) was a Sorbonne law school graduate. He was little influenced by the metanormative obsessions of classic islâh with ijtihâd, and more straightforwardly targeting legal and institutional reconstruction. However, his platform of departure was a vision very close to the one campaigned by Rida. This view was included in his second Ph.D. thesis in comparative law from the University of Lyon, published in 1926. In pleading the reinstitution of caliphal authority, Enid Hill credits his engagement in this thesis with "youthful effort" and "a certain idealism," but also recognizes that his perspective on Islamic law and institutions was to orient his work for the rest of his life (Hill, 1987: 26). The view of caliphal authority as grounded on knowledge and the faculty of ijtihâd-s perfectly coherent with Ridâ's islâhî blueprint. The difference was in the clear awareness that, for any such Islamic authority and lawfulness to function, a modernization of shari'a achieved through a legal-scientific approach to the texts of classic and contemporary jurisprudence, was imperative.

31 Codification through the adoption of the comparative method was al-Sanhûrî's view and method, for which shari'a stood as one of the three major traditions of legal thought and practice along with Roman and Anglo-Saxon law. In this, he turned the islâh's concern for working out principles of lawfulness for the whole community into a project elaborating categories of law specific to the heritage of shari'a, though manuals 
and even early attempts at codification, from the end of the 19th century (like Qadrî's), included no explicit formulations of such categories. The comparative approach was essential to this task. His long preparative work of civil codes, which were later adopted in Egypt, Iraq and Syria, aimed to establish a general codification, that went beyond shari' $a$. In the 1930s and 1940s, there was an acute need for more complete codes to fill the existing gaps in legislation, that even the modern jurisprudence of National Courts, largely inspired by sharî' $a$, had been unable to remedy.

Al-Sanhûrî's approach was neither merely theoretically metanormative, nor adaptivepragmatic. The main issue was the prescriptive efficacy of shari'a,accomplished by establishing obligations and rights conform with the norms therein. They would be implemented, via largely a well-functioning, reformed and rationalized legal system. This was nothing new. It was, in fact, an unquestioned commitment of islâh, as manifested by the efforts of Muhammad 'Abduh. But as soon as shari'a was reified in a concept embodying a normative-systemic rationality in principle, independent from the traditional corpus of scholarly texts of figh, the islâh saw sharî'a'saspirations to metanorm blocked by an irresolvable dilemma. What was to be gained from essentializing normative reason solely on the basis of scripture, while being confronted with the progressive marginalization of legal texts and institutions that appeared too inflexible to catch up with modern standards? Colonial pressure was demanding a law whose outer form could be promptly recognized as fitting the requirements of a modern legal system. As the one major intellectual factor in the first constitution of a modern public sphere built on the rationale of public virtue implemented for the common good, the islâh had developed a highly principled, largely new, but very abstract vision of lawfulness and shari'a. However, by the time national agitation against colonial influence became successful in the 1920s, the need for a better functioning legal system became more acute. At the same time, the necessity to accommodate colonial preferences to keep shari'a's influence on the legal system as invisible as possible was attenuated. It is, however, important to point out that the culmination of islâh is"idealism" (in fact of its metanormative utopianism, like in the view of a new caliphate as the supreme instance of ijtihâd as "free reasoning") with Rida was the necessary departure point. Al-Sanhûrî, on the other hand, provided a programmatic, comparative, and scientific effort at selection and functionalization of Islamic jurisprudence for the reconstruction and reinstitutionalization, of shari'a. This reinstitutionalization was completely bound to fit the requirements of the nation-state, and did not allow for any transnational embodiment of shar'i authority. The beginnings of a solution to the dilemma of how to reinstitutionalize sharîa coincided with the dissolution of islâh's original, uncompromised meta-normative ambitions.

\section{BIBLIOGRAPHIE}

'Abd al-Râziq, 'Ali, 1925, al-islâm wa usûl al-hukm, Cairo: Matba'at Misr 
Alleaume, Ghislaine, 1989, "Linant de.Bellefonds (1799-1883) et le saint-simonisme en Egypte," in: Magali Morey éd., Les Saint-Simoniens et l'Orient. Vers la modernité, Aix-en-Provence: Édisud.

Brown, Nathan J.:

- 1995, "Law and Imperialism: Egypt in Comparative Perspective," Law \& Society 29:103-25.

- 1997, "Sharî' $a$ and State in the Modem Muslim Middle East," International Journal of Middle East Studies 29:359-76.

Dupret, B., 1995, "Autorité et consultation en Islam. Présentation et traduction annotée des commentaires de Fakhr al-Dîn al-Râzî, Rashîd Rida et Sayyid Qutb sur Cor. Ill, 104 et 159," Annales islamologiques XXIX: 233-281

Goldberg, J., 1997, "L'Europe au-delà de l'Europe : réflexions sur l'entrée de l'Egypte dans la famille française du droit," in: G. Boëtsch, B. Dupret and J.-N. Ferrie eds, Droits et sociétés dans le monde arabe. Perspectives socio-anthropologiques, Aix-en-Provence: Presses Universitaires d'AixMarseille

Gran, Peter, 1979, Islamic Roots of Capitalism. Egypt, 1760-1840, Austin and London: University of Texas Press.

Hallaq, W. B., 1984, "Was the Gate of Ijtihâd Closed ?" International Journal of Middle East Studies 16:3-41.

Hill, Enid, 1987, Al-Sanhuri and Islamic Law, Cairo: Cairo Papers in Social Sciences.

Hourani, Albert, 1983 [1962], Arabic Thought in the Liberal Age. 1798-1939, Cambridge: Cambridge University Press.

Johansen, Baber:

- 1988, "Die sündige, gesunde Amme. Moral und gesetzliche Bestimmung (hukm) im islamishen Recht," Die Welt des Islams 28:263-282.

- 1993, "Legal Literature and the Problem of Change: the Case of Land Rent," in: Chibli Mallat éd., Islam and Public Law. Classical and Contemporary Studies, London: Graham \& Trotman.

Kerr, Malcolm, 1966, Islamic Reform. The Political and Legal Theories of Muhammad Abduh and Rashid Rida, Berkeley: Berkeley University Press.

al-Kûmî, Silmî 'Abd-al-'Azîz, 1992, al-sihâfa al-islâmiyya fî misr fi-l-qarn al-tâsi' 'ashar, Mansûra: Dar al-wafâ' li-l-tibâ'a wa-l-nashr wa-l-tawzî'.

Luhmann, Niklas, 1995, Das Recht der Gesellschaft, Frankfurt a.M.: Suhrkamp.

Merad, Ali, 1978, "Islâh",The Encyclopedia of Islam, New Edition, vol. IV, Leiden: Brill.

Rida, Rashîd M., 1988 [1922], al-Khilâfa, Cairo: al-Zahrâ' li-l-i'lâm al-'arabî.

Salvatore, Armando:

- 1997, Islam and the Political Discourse of Modernity, Reading, Berkshire: Ithaca Press.

- 1998, "Staging Virtue: The Disembodiment of Self-Correctness and the Making of Islam as Public Norm," Yearbook of the Sociology of Islam 1.

Smith, Wilfred Cantwell:

- 1962, The Meaning and End of Religion, New York: Macmillan.

- 1965, The Concept of Sharî́a Among Some Mutakallimun," in: George Makdisi éd., Arabic and Islamic Studies in Honor of Hamilton A.R. Gibb, Cambridge, MA: Harvard University Press. 
INDEX

Mots-clés : islam, réforme religieuse, religion, sharî’a, loi islamique

\section{AUTEUR}

\section{ARMANDO SALVATORE}

Humboldt-Universität, Berlin 